\title{
A Eterna Crise Global Provocada pelo Preço do Petróleo
}

Na presente matéria faz-se uma rápida análise do impacto dos preços do petróleo na economia, das perspectivas de aumento na demanda dos derivados de petróleo e da suscetibilidade dos instrumentos financeiros à conjuntura internacional. Mesmo com grande possibilidade de crescimento do mercado petroquímico brasileiro, alerta-se para a necessidade de união dos recursos acadêmicos e empresariais para a busca de substitutos renováveis do petróleo. A oportunidade dessa abordagem é justamente a visão de futuro que traz, ao conclamar a sociedade a assumir seu papel.

Nos últimos meses, voltou à cena uma prática popular e cada vez mais arriscada de se emitir pareceres sobre o comportamento futuro dos preços do petróleo, e os conseqüentes impactos disso na economia brasileira e, mais especificamente, no segmento das indústrias químicas e petroquímicas.

No ano 2000 o que presenciamos foi um panorama que nos trouxe de volta os antigos conflitos no Oriente Médio envolvendo os principais países produtores de petróleo, acrescido do aumento considerável do consumo em alguns grandes países, como por exemplo a China, em contrapartida a uma limitação na capacidade de produção e refino de outros como alguns países europeus e mesmo os Estados Unidos da América.

Dois novos agravantes mundiais porém, colaboraram para gerar um cenário mais preocupante este ano com relação ao preço do petróleo: o intenso frio que se abateu sobre o hemisfério norte e uma amplificação da especulação, que transformou esse mercado em um setor sofisticado da economia mundial, já que agora ele não depende mais apenas da oferta e da demanda, mas de uma série de instrumentos financeiros extremamente sensíveis a qualquer mudança no humor da conjuntura internacional.

$\mathrm{O}$ que fica muito claro para as indústrias químicas e petroquímicas é que o futuro já está traçado há algum tempo. Nele, a uma crescente demanda do petróleo se contrapõem estoques e reservas mundiais do produto cada vez mais reduzidos. E por isso mesmo, a cada dia que passa se torna mais importante ainda a opção por estudar e aplicar novas fontes alternativas, investir na reciclagem e na redução substancial de desperdícios.

Pesquisas e estimativas conservadoras indicam que a proliferação de carros em todo o mundo deve aumentar o consumo global de petróleo, de 76 milhões de barris por dia atualmente, para 115 milhões de barris por dia até 2020 . Os mais otimistas prevêem duplicar a demanda mundial de energia nos próximos dez anos e quadruplicar esse consumo até o fim do novo século.

Enquanto isso, aqui no Brasil, vivemos mais uma vez uma si- tuação curiosa: ao mesmo tempo em que se fala em uma programação com certa freqüência de reajuste dos combustíveis, e as centrais petroquímicas e a Petrobrás negociam a definição do preço da nafta e seus derivados, as seis indústrias petroquímicas de capital aberto do País comemoram lucros contábeis em seus balanços, cinco vezes maiores comparados aos números do ano passado.

Esses números se justificam pelo crescimento marcante da demanda interna, que conseguiu a proeza de, inclusive, superar os graves problemas registrados no mercado interno com o impasse na definição sobre o preço da nafta. Uma discussão que começou quando o governo liberou o preço da matéria-prima básica consumida pelas centrais petroquímicas.

De qualquer forma o ano foi considerado bom para as indústrias petroquímicas brasileiras, embora se saiba que os números do primeiro semestre não se repetirão no segundo, principalmente em função dessa cadeia de fatores que levou a um comportamento errático do preço inter- 
nacional do petróleo e seus derivados.

O mercado petroquímico brasileiro ainda tem muito espaço para crescer e se desenvolver, mas sem um impulso proveniente do mercado de capitais isso torna-se improvável e inviável. O caminho mais bem traçado para esse crescimento passa pela busca por avanços científicos que levem ao desenvolvimento de substitutos renováveis ao petróleo; políticas oficiais internas que permitam evitar que a volatilidade desse mercado mundial possa ameaçar a integridade das indústrias nacionais; nova postura gerencial dos executivos que estão à frente desse negócio, de forma a agirem com planejamento, ousadia e capacidade empreendedora.

Esperar por soluções importadas, nesse caso, não gerará provavelmente um bom resultado... ao contrário de outras causas de impacto global como cura da AIDS ou recomposição das florestas, a substituição do petróleo merece prioridade diferenciada de cada nação dependendo do seu grau de dependência ou suficiência. A solução para o Brasil, portanto, deverá ser encontrada pelos brasileiros. A utilização racional dos recursos acadêmicos e empresariais disponíveis no país coordenados por suas asso-

\section{Reservas mundiais de petróleo}

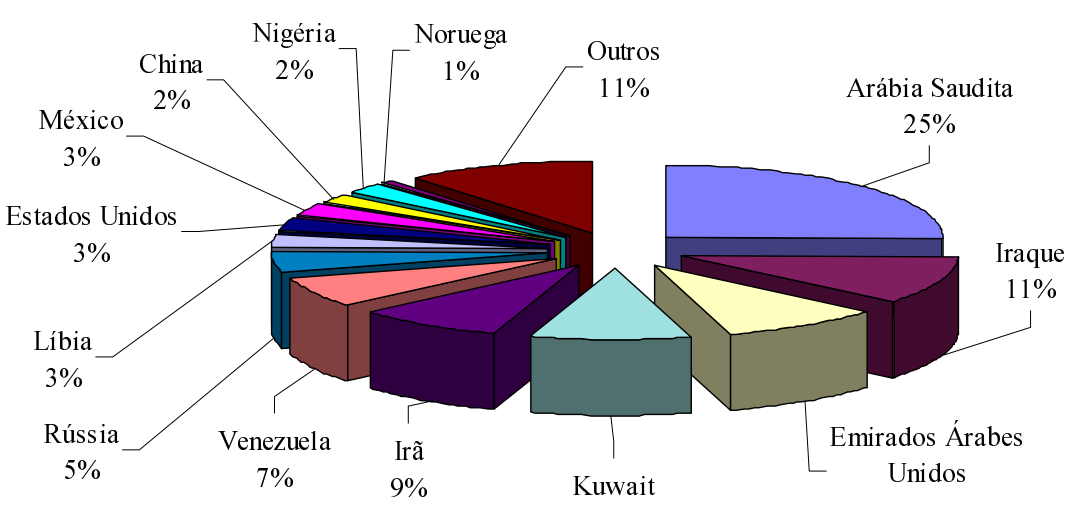

Produção Mundial de Petróleo

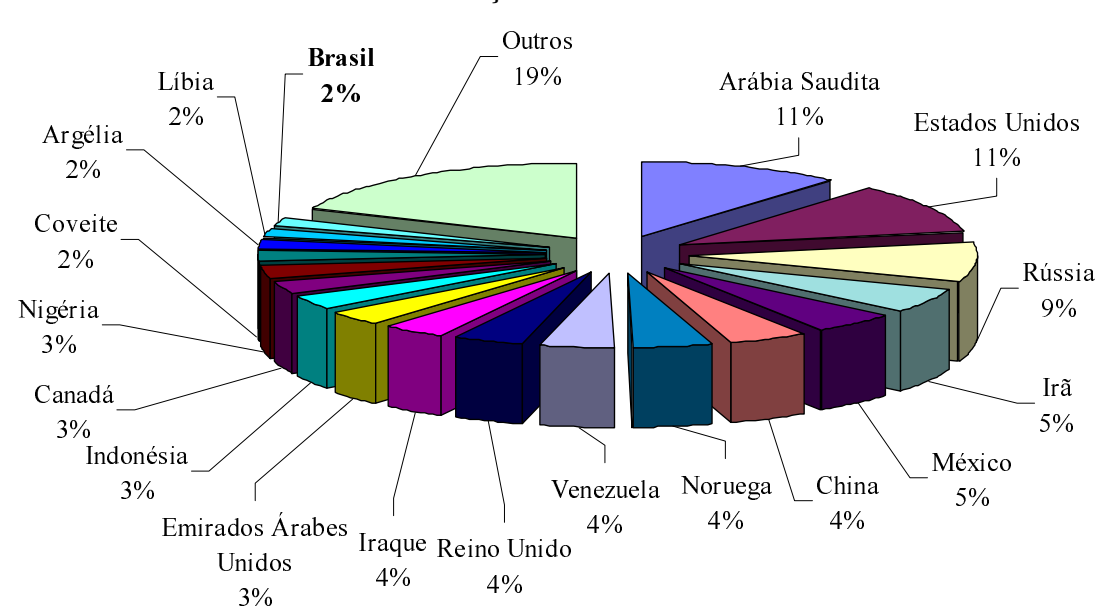

ciações representativas poderá ser um dos canais mais efetivos para viabilizar as iniciativas de enfrentar esses desafios.

A ABPol e as demais associações representativas dos interesses da comunidade científica e empresarial do segmento de polímeros devem assumir a sua responsabilidade nesse contexto e coordenar os esforços para a realização desse projeto.

Domingos Jafelice, diretor da DSM South America Ltda. 